\title{
DENDROFLORA OF MANOR GARDENS OF THE EARLY TWENTIETH CENTURY IN ŁĘCZNA COUNTY
}

\author{
Margot Dudkiewicz, Marek Dąbski \\ Institute of Ornamental Plants and Landscape Architecture, University of Life Sciences in Lublin \\ Głęboka 28, 20-612 Lublin, Poland \\ e-mail: margotdudkiewicz@o2.pl
}

Received: 26.06.2013

\begin{abstract}
In the late nineteenth and the early twentieth centuries, new styles in the concept of a naturalistic park were created. The sites from this period located in the Lublin region include, among others, the Milejów manor and the Ciechanki Łańcuchowskie manor. The manor park in Milejów was founded in the nineteenth century in English style. In the park there is a wooden, well-preserved mansion from 1903. However, the manor in Ciechanki is a building in modernist style. Both these park and manor complexes have a rich history and they fully deserve conservator's protection. A dendrological inventory in Milejów showed 190 woody plants belonging to 22 species, while in Ciechanki - 590 woody plants belonging to 24 species. They are mostly native species associated with deciduous forests - Fraxinus excelsior L., Acer pseudoplatanus L., and Carpinus betulus L. Currently, the parks are gradually becoming naturalised, losing their original spatial arrangement, and they require restoration.
\end{abstract}

Key words: dendroflora, Milejów, Ciechanki Łańcuchowskie, manor parks

\section{INTRODUCTION}

In the agricultural landscape, post-manor parks are a substitute for a forest. Although the species composition of such parks differs from that of a typical forest, yet they play many environmental functions, e.g. they constitute elements of ecological chains which enable the migration of organisms between biotopes and ecological niches isolated from civilization [1]. Historic green residential complexes represent typical trends from the Renaissance and Baroque as well as various types of landscape parks which constitute the primary means of shaping the surroundings of countryside mansions [2]. A landscape park is a space made up of different images and sequences of places such as grass areas, irregular and free forms of woody vegetation and water features of natural character - ponds and streams. Sometimes, a regular garden next to a mansion building, while spreading, changes into an English-style park and finally permeates the landscape to become a part of woodland. B or o w s k i et al. [3] pointed out that the vegetation of the parks can vary structurally (woodland, grassland), in terms of habitat (e.g. riparian wetland habitats, typical hornbeam patches), and in the degree of conversion (degenerated groups and groups of natural character) [3].

New styles of parks: calligraphy, art nouveau, classical, modernist and regional, derived from the concept of naturalistic park, were created in the late nineteenth and the early twentieth centuries [4].

The historic manor and palace complexes with green areas are a valuable part of the cultural heritage of the Lublin region. Eęczna County, located in the central part of Lublin Province, is on the border of two geographic regions - Lublin Upland and Lublin Polesie. The landscape of the region is dominated by vast flat plains varied by gentle moraine hills. Their surface is covered with numerous groves and forests, among which there are many lakes, swamps and bogs. Around Łęczna, there are significant height differences within the Wieprz River gorge, recognised as one of the most beautiful Polish landscapes [5].

In 1855 Antoni Rostworowski became the owner of Milejów and since then there was a rapid economic development of the village [6]. In the early twentieth century, the manor house was surrounded by parkland and orchards. From the south, it was an apple tree orchard, from the east a pear tree orchard, while from the north a plum tree orchard. Around the 
building, there were flowerbeds with herbs. Also the main alleys in the orchards were decorated with multicolored flowerbeds. Two hornbeam alleys led from the manor to the nearby distillery and vegetable gardens, cold frames and a conservatory were situated along these alleys. During the period of the Polish People's Republic, $70 \%$ of the former park was occupied by the Fruit Company in Milejów. A part of the park was converted into a square where new trees and shrubs were planted. The remaining area of the Milejów estate was divided into many smaller parcels.

The Milejów manor, built by Antoni Roztworowski in 1903, was designed by Jan Heurich. Now there remains only $30 \%$ of the area of the former park. On the basis of the layout of the oldest trees, it can be concluded that the park was free style composition, naturalistic and perhaps under the influence of Art Nouveau.

The study by K se niak and Gralew ski of 1987 [7] says that in the remains of the park there were approximately 180 trees belonging to 15 species. The most numerous were as follows: Fraxinus excelsior L. (50 individuals), Aesculus hippocastanum L. (35), Tilia cordata Mill. (25), Acer platanoides L. (25), Carpinus betulus L. (20), Robinia pseudoacacia L. (20), and Picea abies H.Karst. (5). From rare taxa, there was Abies concolor Lindl. ex Hildebr. and Fraxinus excelsior 'Pendula'. Bushes near the banks of the Wieprz River consisted of seven species of shrubs and young trees. The most numerous were: Sambucus nigra L., Syringa vulgaris L., Symphoricarpos albus S.F.Blake. as well as brushwood of Acer platanoides L., and Fraxinus excelsior L. [7].

Since 1908, the Ciechanki property belonged to the Lachert family. The nineteenth century manor house was rebuilt in 1924 by the architect Bogdan Lachert as the first project in the modernist style, which simplified the form of the Polish manor by adapting it to the needs of the pre-war village $[8,9]$. The property is entered in the Register of monuments of Lublin region under number $\mathrm{A} / 732$.

On the axis of the manor house, on the east side there was an oval driveway, whereas on the axis of the garden elevation - the original transportation system was developed in the form of three long fan-shaped alleys. The major roads led to the pond, the orchard, the vegetable garden, and the farm buildings.

The manor complex in Ciechanki Łańcuchowskie belongs to parks in modernist style with elements of a calligraphic park. According to an inventory made by Kseniak and Fijałkowski in 1976 [7], the park consisted of 600 trees representing 32 species. The most numerous were: Carpinus betulus L. (150 individuals), Betula pendula Roth and Populus nigra L.
(120); Picea abies H.Karst. (80); Fraxinus excelsior L. and Acer platanoides L. (50); Tilia cordata Mill. (40), Acer pseudoplatanus L., Aesculus hippocastanum L., Salix alba L. (20), and Quercus robur L. (15) [10,11].

The aim of this study was to make a dendrological inventory in two manor gardens of the early twentieth century in Łęczna County and then, on the basis of the collected data, to assess the state and value of woody plants as well as to determine the most important recommendations on tree stand management.

\section{MATERIALS AND METHODS}

A field study carried out in 2010 (Milejów) and in 2011 (Ciechanki Łańcuchowskie) included an inventory of the stand and an overall inventory of architectural buildings. A detailed dendrological inventory was based on the measurement of trees in the study area, together with drawing them on a geodetic map. All inventoried trees and groups of shrubs were marked on a geodetic map using the method of simple perpendicular coordinates measured with a Leica DISTO A5 laser rangefinder. In addition, natural monuments were located in the area with a DAKOTA positioning device (GPS). The analysis of the estimated age of trees was based on the table of the tree age structure developed by Majde cki [1980-1986] [12]. The time periods of plantings were based on the generally known dates of changes in the ownership of the properties or of the conversion of the manor houses which involved the reconstruction of the parks.

\section{RESULTS}

\section{The Milejów manor}

Milejów - a village in Łęczna County, is located $35 \mathrm{~km}$ south-east of Lublin. The remains of the manor park cover an area of $2 \mathrm{ha}$. The property is not listed as a historic monument.

\section{Dendrological inventory of the park}

In 2010, in the Milejów park a total of 216 specimens were inventoried, including 190 trees, 16 shrubs and two groups of bushes, two groups of undergrowth of trees and six hedges (Table 1). The stand of the park represents 22 species and varieties of trees. In terms of the number of trees, the following predominate: Fraxinus excelsior L. (38 individuals), Acer pseudoplatanus L. (26), Aesculus hippocastanum L. (25), and Pyrus pyraster Burgsd. (21) (Fig. 1). Among the remains of the park in Milejów there are two nature monuments: Tilia cordata Mill. (with a circumference of 590 $\mathrm{cm}$ and a height $15 \mathrm{~m}$ ) and Tilia cordata Mill. (circ. $440 \mathrm{~cm}$, height $10 \mathrm{~m}$ ). On the basis of the inventory 
conducted in 2010 to protect the nature monuments, two specimens were selected: Fraxinus excelsior L. (circ. $330 \mathrm{~cm}$, height $20 \mathrm{~m}$ ) and Fraxinus excelsior L. (circ. $330 \mathrm{~cm}$, height $25 \mathrm{~m}$ ). Two major groups of Acer platanoides L. constitute brushwood with trees in the park. There were also identified 16 shrubs and two groups of bushes belonging to seven species: Cornus alba L., Corylus avellana L., Cotinus coggygria Scop., Forsythia xintermedia Zabel, Sambucus nigra L., Taxus baccata L., and Syringa vulgaris L. Next to the manor buildings and residential blocks, there are 6 hedges: Ligustrum vulgare L., Acer platanoides L., and Cotoneaster lucidus Schltdl. The ground cover consists of three groups of plants: Fraxino-Alnetum, Lolio-Cynosuretum and Filipendula ulmaria L., Arctium lappa L. and Urtica dioica $\mathrm{L}$.

In the years 1987 and 2010 which were compared, a similar number of trees were observed in the park in Milejów - 180-190 individuals. In 2010 there was a slightly greater diversity of species composition. The number of tree species and varieties increased from 15 to 22 relative to 1987 and there was no major change in the undergrowth. There is an equal number of shrub species and similar brushwood to Acer platanoides L. and Fraxinus excelsior L.

Table 1

List of tree species and varieties in the Milejów park in 2010

\begin{tabular}{|c|c|c|c|c|c|}
\hline \multirow[b]{2}{*}{ No. } & \multirow[b]{2}{*}{ Name } & \multirow[b]{2}{*}{$\begin{array}{l}\text { Number of } \\
\text { trees }\end{array}$} & \multicolumn{3}{|c|}{ The largest dimensions of specimens } \\
\hline & & & $\begin{array}{c}\text { Girth at a height of } \\
1.3 \mathrm{~m} \\
{[\mathrm{~cm}]}\end{array}$ & $\begin{array}{l}\text { Height } \\
{[\mathrm{m}]}\end{array}$ & $\begin{array}{c}\text { Tree crown } \\
\text { diameter } \\
{[\mathrm{m}]}\end{array}$ \\
\hline 1. & Abies concolor Lindl. ex Hildebr. & 1 & 90 & 15 & 3 \\
\hline 2. & Acer negundo L. & 2 & 115 & 8 & 5 \\
\hline 3. & Acer platanoides $\mathrm{L}$. & 17 & 210 & 15 & 10 \\
\hline 4. & Acer pseudoplatanus $\mathrm{L}$. & 26 & 300 & 20 & 15 \\
\hline 5. & Aesculus hippocastanum L. & 25 & 290 & 15 & 10 \\
\hline 6. & Betula pendula Roth & 1 & 30 & 5 & 3 \\
\hline 7. & Carpinus betulus L. & 9 & 235 & 15 & 10 \\
\hline 8. & Crateagus monogyna Jacq. & 5 & 80 & 5 & 4 \\
\hline 9. & Euonymus europaeus L. & 1 & 30 & 4 & 4 \\
\hline 10. & Fraxinus excelsior L. & 38 & 330 & 20 & 15 \\
\hline 11. & Larix decidua Mill. & 1 & 215 & 20 & 15 \\
\hline 12. & Malus.domestica Borkh. & 10 & 170 & 10 & 5 \\
\hline 13. & Picea abies H.Karst. & 2 & 210 & 20 & 10 \\
\hline 14. & Pinus sylvestris L. & 1 & 15 & 3 & 2 \\
\hline 15. & Populus nigra L. & 5 & 330 & 25 & 15 \\
\hline 16. & Pyrus pyraster Burgsd. & 21 & 110 & 8 & 6 \\
\hline 17. & Quercus robur L. & 1 & 90 & 10 & 5 \\
\hline 18. & Robinia pseudoacacia L. & 2 & $290+240$ & 15 & 15 \\
\hline 19. & Salix alba $\mathrm{L}$ & 1 & 30 & 8 & 5 \\
\hline 20. & $\begin{array}{l}\text { Salix 'sepulcralis Simonk. } \\
\text { 'Chrysocoma' }\end{array}$ & 4 & 370 & 20 & 15 \\
\hline 21. & Tilia cordata Mill. & 14 & 590 & 15 & 20 \\
\hline 22. & Ulmus laevis Pall. & 3 & 130 & 20 & 15 \\
\hline
\end{tabular}

Total: 190 


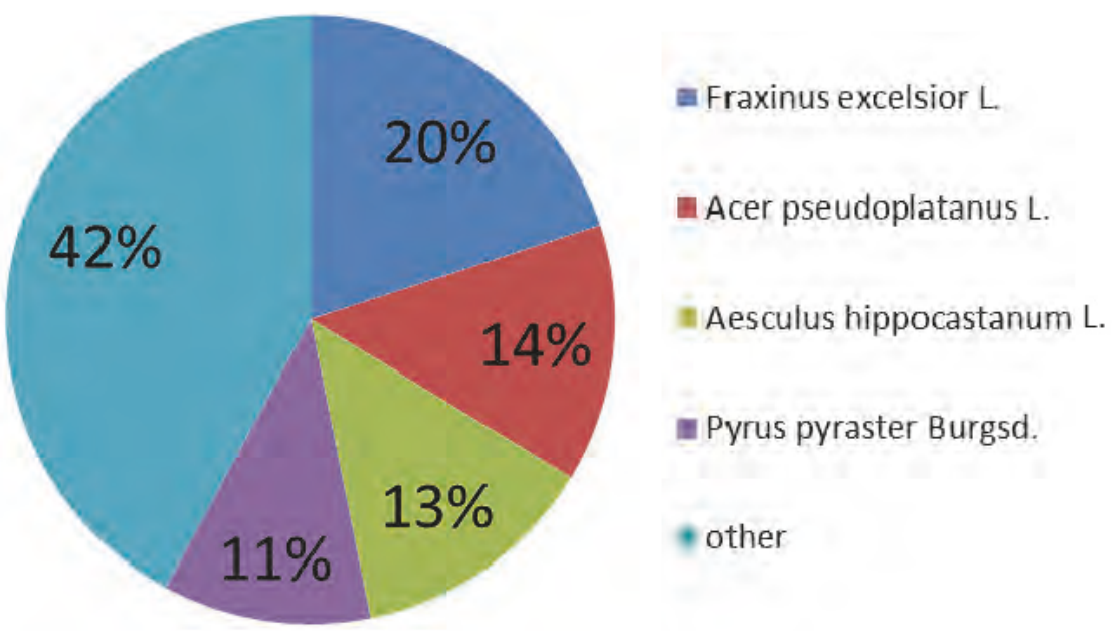

Fig. 1. Percentage of the most common tree species in the Milejów park in 2010.

\section{Age analysis of trees}

The age analysis showed a predominance of young plantings of trees and shrubs (55 individuals) and trees at the age of 21-65 years (123 individuals) (Table 2 ). The park has five trees planted in the period 19071945 and seven valuable specimens older than 100 years.
The vegetation of the post-manor park is the largest green complex in the area. Despite the loss in its area, historic stand and composition, the park is still a valuable part of the landscape of the village and a recreational place for the residents of Milejów.

Table 2

The age structure of trees in the post-manor park in Milejów in 2010

\begin{tabular}{lccc}
\hline \multicolumn{1}{c}{ Planting time period } & Tree age & Number of trees & Percentage \\
\hline $\begin{array}{l}\text { 1990-2010 - trees planted in the last two decades } \\
\text { 1946-1989 - trees planted after World War II in the park used by }\end{array}$ & Up to 20 years & 55 & $29 \%$ \\
the Agricultural Cooperative & $21-65$ years & 123 & $64 \%$ \\
$\begin{array}{l}1908-1945 \text { - trees planted in the formative period of the park } \\
\text { in the current landscape }\end{array}$ & $66-102$ years & 5 & $3.4 \%$ \\
Time before 1908 - the manor house with a garden & Trees older than 120 years & 7 & $3.6 \%$ \\
\hline
\end{tabular}

\section{The manor compex}

\section{in Ciechanki Łańcuchowskie}

Ciechanki Łańcuchowskie is a village in Puchaczów Commune, $30 \mathrm{~km}$ east of Lublin. The manor complex is located in the vicinity of pine forests. The landscape park with farm buildings covers an area of 6.5 ha.

\section{Dendrological analysis of vegetation}

In 2011, within the area of the park and manor in Ciechanki Łańcuchowskie, a total of 617 specimens were inventoried, including 590 trees, 6 single specimens of shrubs and three larger groups of bushes, two groups of trees, 14 groups of undergrowth and two hedges (Table 3 ).

The stand of the park in Ciechanki Łańcuchowskie represents 24 species of trees. In terms of num- bers, the following are predominant: Fraxinus excelsior L. (157 individuals), Acer pseudoplatanus L. (83), Acer platanoides L. (70), Carpinus betulus L. (61), and Tilia cordata Mill. (51) (Fig. 2). On the basis of an inventory of trees designated for natural monument protection, 11 specimens were identified, including Fraxinus excelsior $\mathrm{L}$. (with a circumference of 450 $\mathrm{cm})$ and Pinus nigra J. F. Arnold $(380 \mathrm{~cm})$.

Brushwood consists of nine species of trees and shrubs, with a quantitative predominance of the following: Acer platanoides L., Fraxinus excelsior L. and Sambucus nigra L. In comparison to the 1976 inventory, the following plantings disappeared: Crateagus monogyna Jacq., Euonymus europaeus L., Euonymus verrucosus L., Cornus sanguinea L., and Ulmus minor Mill. emden. Richens, and were replaced by expan- 
sive species such as Sambucus nigra L. and Symphoricarpos albus S. F. Blake.

The edges of the ponds are covered with marsh vegetation with a predominance of Typha angustifolia L. The ground cover is dominated by plants of the following groups: Arrhenatheretum elatioris Br.Bl.ex Scherr, Sambucetum nigrae Oberd. and Arctietum nemorosi $\mathrm{R}$. Tx.
In the years compared (1976 and 2011), there was an equal number of trees. At the same time, the depletion of the species composition from 32 in 1976 to 24 species in 2011 was easily noticeable. However, the most numerous were: Fraxinus excelsior L., Acer pseudoplatanus L. and Acer platanoides L. The process of replacement of the stand with self- seeders is observed.

Table 3

List of tree species and varieties in the Ciechanki Łańcuchowskie park in 2011

\begin{tabular}{|c|c|c|c|c|c|}
\hline \multirow[b]{2}{*}{ No. } & \multirow[b]{2}{*}{ Name } & \multirow[b]{2}{*}{$\begin{array}{c}\text { Number of } \\
\text { trees }\end{array}$} & \multicolumn{3}{|c|}{ The largest dimensions of specimens } \\
\hline & & & $\begin{array}{c}\text { Girth at a height of } \\
1.3 \mathrm{~m} \\
{[\mathrm{~cm}]}\end{array}$ & $\begin{array}{c}\text { Height } \\
{[\mathrm{m}]}\end{array}$ & $\begin{array}{c}\text { Tree crown } \\
\text { diameter } \\
{[\mathrm{m}]}\end{array}$ \\
\hline 1. & Abies concolor Lindl. ex Hildebr. & 1 & 270 & 10 & 9 \\
\hline 2. & Acer negundo L. & 4 & 140 & 6 & 7 \\
\hline 3. & Acer platanoides $\mathrm{L}$. & 70 & 270 & 9 & 8 \\
\hline 4. & Acer pseudoplatanus $\mathrm{L}$. & 83 & 270 & 8 & 6 \\
\hline 5. & Acer saccharinum $\mathrm{L}$. & 2 & 110 & 7 & 6 \\
\hline 6. & Aesculus hippocastanum L. & 18 & 240 & 10 & 10 \\
\hline 7. & Betula pendula Roth & 15 & 220 & 8 & 7 \\
\hline 8. & Carpinus betulus $\mathrm{L}$. & 61 & 200 & 8 & 6 \\
\hline 9. & Fraxinus excelsior L. & 157 & 450 & 15 & 10 \\
\hline 10. & Malus domestica .Borkh. & 2 & 80 & 4 & 5 \\
\hline 11. & Morus alba $\mathrm{L}$. & 4 & 150 & 6 & 7 \\
\hline 12. & Picea abies H.Karst. & 40 & 220 & 9 & 8 \\
\hline 13. & Pinus nigra J. F. Arnold & 5 & 380 & 12 & 12 \\
\hline 14. & Populus nigra L. & 37 & 450 & 12 & 10 \\
\hline 15. & Prunus domestica subsp. syriaca Janch. & 1 & 50 & 4 & 5 \\
\hline 16. & Pyrus pyraster Burgsd. & 3 & 140 & 5 & 6 \\
\hline 17. & Quercus palustris Muenchh. & 8 & 200 & 10 & 8 \\
\hline 18. & Quercus robur L. & 8 & 260 & 10 & 8 \\
\hline 19. & Robinia pseudoacacia $\mathrm{L}$. & 8 & 200 & 10 & 6 \\
\hline 20. & Salix alba $\mathrm{L}$. & 10 & 470 & 15 & 12 \\
\hline 22. & Thuja occidentalis L. & 1 & 40 & 2 & 3 \\
\hline 23. & Tilia cordata Mill. & 51 & 350 & 10 & 10 \\
\hline 24. & Ulmus laevis Pall. & 1 & 150 & 6 & 7 \\
\hline
\end{tabular}




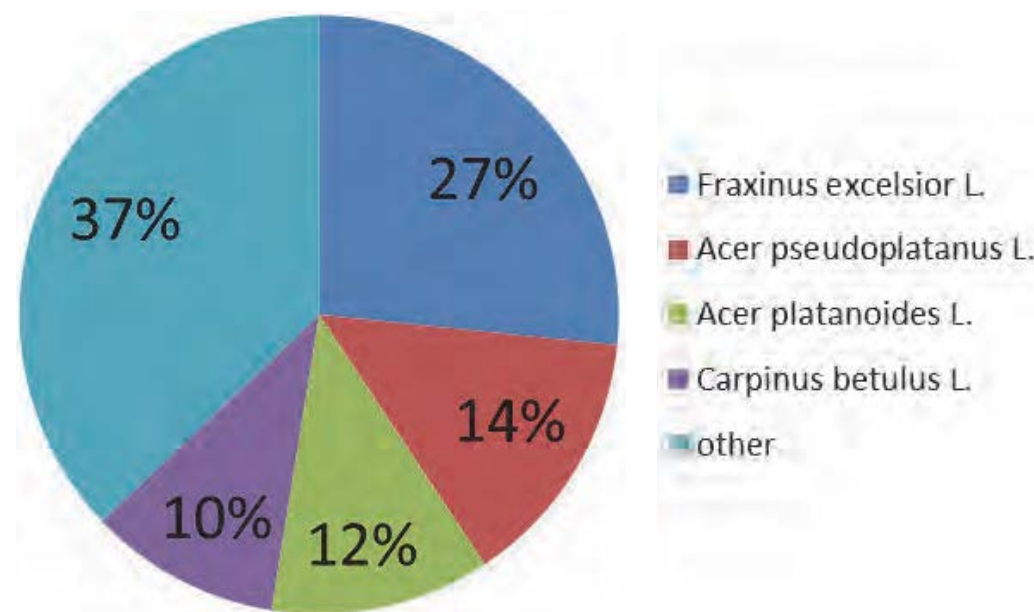

Fig. 2. Percentage of the most common tree species in the post-manor park in Ciechanki Łańcuchowskie in 2011

\section{Age analysis of trees}

The age analysis showed that the predominant trees in the park are under the age of 20 years (114 individuals) and 21-65 years (423 individuals) (Table 4).
The remaining 28 trees are at the age from 66 to 87 years and there are 25 valuable specimens over the age of 87 years from the period of the formation of the Art Nouveau ornamental park.

Table 4

The age structure of trees in the post-manor park in Ciechanki Łańcuchowskie in 2011

\begin{tabular}{|c|c|c|c|}
\hline Planting time period & Tree age & Number of trees & Percentage \\
\hline 1990-2011 - trees planted in the last two decades & Up to 20 years & 114 & $19 \%$ \\
\hline $\begin{array}{l}\text { 1946-1989 - trees planted after World War II in the park used } \\
\text { by the Agricultural Cooperative }\end{array}$ & $21-65$ years & 423 & $72 \%$ \\
\hline $\begin{array}{l}\text { 1924-1945 - trees planted in the formative period of the park } \\
\text { in landscape style }\end{array}$ & $66-87$ years & 28 & $4.8 \%$ \\
\hline Time before 1924 - the manor house with a park and a farm & trees older than 87 years & 25 & $4.2 \%$ \\
\hline
\end{tabular}

The stand of the park is dense with brushwood of self-seeders. In the last few decades, the park and manor complex has been largely neglected. Garages and outbuildings destroy the general view of the area. The lack of care as well as the progressive obliteration and destruction of plants have resulted in the impoverishment of its dendroflora.

\section{SUMMARY AND CONCLUSIONS}

In both parks analysed, a lot of seedlings and undergrowth grow, which allows for natural regeneration of the dominant species. The stand structure in these sites is based on national forest species. The most frequently occurring introduced species are Robinia pseudoacacia L., Aesculus hippocastanum L. and Pinus nigra J.F. Arnold. The undergrowth is like a meadow with a large proportion of ruderal plants. There are neglected species in the wetland area of the parks and their structure changes in the riparian wetland. The tree stand in the hilly and dry areas is becoming impoverished and the place of rare tree species of the era of the landscape parks is occupied by hornbeam plants of outstanding natural beauty. In both parks the natural succession is observed.

\section{Acknowledgments}

The study was performed under a research grant received from the Ministry of Science and Higher Education for the Department of Ornamental Plants and Landscape Architecture at the University of Life Sciences in Lublin.

\section{Authors' contributions}

The following declarations about authors' contributions to the research have been made: concept of the study: M. Dąbski; field work: M. Dudkiewicz; writing: M. Dąbski, M. Dudkiewicz. 


\section{REFERENCES}

1. Czechowicz M. Zapomniane wartości starych parków [Forgotten values of old parks]. Archit Kraj. 2006; 3-4: 48-55.

2. Majdecka-Strzeżek A. Rewaloryzacja iadaptacjazabytkowych rezydencjonalnych założeń ogrodowych w Polsce, teoria i praktyka postępowania. In: Mitkowska A, Mirek Z, Hodor K, editors. Założenia rezydencjonalno-ogrodowe. Dziedzictwo narodu polskiego na tle europejskich wpływów kulturowych. Cracow: W. Szafer Institute of Botany, Polish Academy of Sciences; 2009. p. 20-33.

3. Borowski J, Sikorski P, Wierzba M, Wy s ocki C. Metody inwentaryzacji roślinności w parkach zabytkowych o charakterze krajobrazowym na podstawach geobotanicznych [Methods of vegetation inventory-making in historical landscape park based on geobotanical knowledge]. Sylwan. 2007; 12: 30-39.

4. Bogdanowski J. Polskie ogrody ozdobne. Warsaw: Wydawnictwo Arkady; 2000.

5. Wilgat J, Albrycht A, Wołoszyn W, Furtak T. editors. Program ochrony środowiska i plan gospodarki odpadami dla powiatu łęczyńskiego. 2004.

6. Kseniak M, Gralewski L. Katalog parków województwa lubelskiego - ewidencja pozostałości zespołu dworsko-parkowego w Milejowie. Lublin: Archiwum WKZ; 1987.

7. Kseniak M, Fijałkowski D. Katalog parków województwa lubelskiego - park w Ciechankach Łańcuchowskich. Lublin: Archiwum WKZ; 1976.

8. Rozbicka M. Dwór w Ciechankach, czyli o modernizmie ,w rzeczywistym zastosowaniu”. In: Dwór polski zjawisko historyczne i kulturowe. Kielce. 2004. p. 473-498.

9. Dudkiewicz M, Iwanek M. Architektura przedwojennego modernizmu na przykładzie dworu w Ciechankach [Pre-war architecture of modernism as an example mansion in Ciechanki]. Acta Sci Pol Form. Circumiectus. 2012; 11(3): 3-12.
10. Fijałkowski D, Kseniak M. Parki wiejskie Lubelszczyzny - stan, ochrona i rewaloryzacja biocenotyczna. Warsaw: Polish Scientific Publishers PWN; 1982.

11. Majdecki L. Tabela wiekowa drzew Rkps. Warsaw: Oddział Architektury Krajobrazu SGGW; 1980.

12. Rost w or ow ski W. Jak wyglądał stary Milejów i jak się tam kiedyś żyło. Wiad Ziemiańskie. 2004; 18: 29-38.

\section{Dendroflora ogrodów dworskich początku XX w. na terenie powiatu łęczyńskiego}

\section{Streszczenie}

Na przełomie XIX i XX w. powstały nowe style w koncepcji parku naturalistycznego. Do obiektów z tego okresu położonych na terenie Lubelszczyzny należą m.in. zespół dworski Milejów i zespół dworski Ciechanki Łańcuchowskie. Park dworski w Milejowie został założony w XIX wieku w stylu nawiązującym do angielskiego. W parku znajduje się drewniany, dobrze zachowany dwór z 1903 r. Natomiast zespół dworski w Ciechankach jest obiektem w manierze modernistycznej. Obydwa założenia rezydencjonalne posiadają bogatą historię i w pełni zasługują na ochronę konsekratorską. Inwentaryzacja dendrologiczna w Milejowie wykazała 190 roślin drzewiastych, należących do 22 gatunków a w Ciechankach - 590 roślin drzewiastych należących do 24 gatunków. Są to głównie gatunki rodzime związane z lasami liściastymi - Fraxinus excelsior L., Acer pseudoplatanus L. i Carpinus betulus L. Obecnie parki ulegają stopniowej naturalizacji zatracając swój pierwotny układ przestrzenny i wymagają rewaloryzacji.

Handling Editor: Elżbieta Weryszko-Chmielewska

This is an Open Access digital version of the article distributed under the terms of the Creative Commons Attribution 3.0 License (creativecommons.org/licenses/by/3.0/), which permits redistribution, commercial and non-commercial, provided that the article is properly cited.

CThe Author(s) 2013 Published by Polish Botanical Society 